\title{
Clinical Legal Education: Bridging the gap between study and legal practice
}

\section{Jessica Kaczmarek and Jacquie Mangan ${ }^{1}$}

For a law student, the academic study of the law and the actual practice of its principles seem worlds apart. With our desk piled high with books, case reports and legislation, the opportunity to experience and reflect upon the human interaction that underpins legal practice is notably lacking. While good lawyer client relationships are vital to successful legal practice, at present, a law student can obtain their law degree without ever interviewing a client or managing a case file. It was with this paradox in mind that during 2000 we embraced the opportunity to be a part of a clinical legal education program run by La Trobe University's School of Law and Legal Studies.

The program involved working voluntarily (but for academic credit) one day a week for ten weeks at Victoria Legal Aid's Preston office. As the program was part of the Legal Practice and Conduct course, the aim of the placement was to explore the legal practitioner's duty to the client, the courts, and fellow practitioners. This was primarily achieved through reflection upon our observation of legal practitioners and from our own personal experience of practising as 'student lawyers'. ${ }^{2}$ Throughout the program we observed client interviews and court appearances conducted by experienced practitioners. This provided us with a firsthand perspective of the legal system and we were encouraged to study and critique each practitioner's different style of interviewing, advocacy and case management.

All students were then given the opportunity to develop their own skills through participation in a student clinic. We interviewed clients, researched matters, wrote letters of demand and advice and, if required, briefed counsel and prepared our clients for their court appearance. At the end of each day we wrote a journal entry about our experience. This encouraged us to reflect upon our own skills and ultimately assisted in our development both as individuals and aspiring lawyers.

The legal aid setting provided an incredibly intense but rewarding learning environment. During the course of the placement we came into contact with people from diverse backgrounds. Our clients included people who were homeless, people suffering from mental and physical disabilities, or drug addictions, and people who had been victims of sexual and physical assault. For the first time, we observed that legal problems were not just a collection of isolated facts, but

1 Fourth Year, Law Arts Undergraduate Students at La Trobe University, Melbourne, Australia.

2 In recognition of the formal requirements for legal practice in the Legal Practice Act (Vic) 1996, all people we dealt with in our capacity as 'student lawyers' were informed that we were law students not qualified legal practitioners. Our clients were assured that legal practitioners holding current practising certificates would approve all advice given and work undertaken on their behalf. 
stemmed from a long and complex history of social problems. Through experiencing the lawyer client relationship we became aware of the inherent contradictions which underpin our legal system. On many instances we had to explain to clients how the limited scope of legal aid meant that we could not help them. While, in other instances, we were obliged to help those whom we felt would not derive any benefit from our efforts or would quickly be returned to the court system.

We often found ourselves in personally confronting situations. We witnessed first hand the inhuman conditions of some suburban police cells. We were reminded of how legal decisions impact on people's lives through seeing a distraught child watch their mother being lead away following a failed bail application. This was a timely reminder of the consequences which stem from legal decisions and the responsibility upon practitioners to give their best efforts. For the first time, when engaging in research we knew that more than just law school marks were at stake. However, we found that our efforts were rewarded when our work helped to resolve a problem in our client's life.

Our months at Preston Legal Aid also showed us the more colorful aspects of practising law. One young student lawyer had to jump out of the way of flying chairs as a client attempted to escape from custody while at court. In our inexperience we found ourselves taking pleasure from the smallest of achievements, our first file, first interview, the first letter personally addressed to us, or our first phone message. Our excitement at each of these 'firsts' was often looked upon with bemusement by our more experienced colleagues and was coupled with the warning that the joy of these things would quickly wear off!

The structure of the program allowed us to experience the full spectrum of work done by a legal aid lawyer. We would spend one week assisting the duty solicitor at the local Magistrates' Court and the next week we would interview clients. This was an ideal situation because it allowed us to observe the duty solicitor for one week and then attempt to put those lessons into practice with our own clients the next week. Our student clinic was a very safe learning environment as we always had the support of our supervisor and other solicitors within the office. The clients were usually very patient with us and one client even remarked that the student lawyers often made more sense that the real lawyers.

The amount we learnt in ten weeks was quite amazing. Through dealing with clients and running client files we developed communication and organizational skills of universal application. We also developed an insight into the duties of the legal practitioner that can only be achieved through practical participation in the process of giving clients legal advice. Our clinical legal education experience challenged us in ways that traditional learning methods do not. It required us to not only know the law, but to learn how to communicate it to others in a meaningful way. It pushed us to look outside of the legal problem and examine the more personal reasons behind the client's troubles.

In essence, an understanding of the law is worth very little unless that understanding can be used to respond to people's needs. A common criticism directed towards the legal profession is that lawyers are good at dealing with other lawyers but not with the wider population. This is a systemic problem which can only be addressed from the ground up. Equipping law students with interpersonal skills is as valuable to their education as learning contract law. Clinical legal education programs do have financial and personal costs. They are more difficult for the law school to run and can place additional pressures upon the student. However, from our experience, participation in a wellstructured clinical legal education program is immensely rewarding as it encourages personal and legal development that simply cannot be achieved from lectures and books. 